\title{
Visit End Date
}

National Cancer Institute

\section{Source}

National Cancer Institute. Visit End Date. NCI Thesaurus. Code C88010.

The calendar date on which a visit ends. 